\title{
'Paddling a canoe with an oar made of oak': the enduring legacy of British law in Pacific island states
}

\author{
Professor Sue Farran
}

Professor of Law, School of Law, Northumbria University

\section{Introduction}

$\mathrm{T}$ The spread of the common law from early conquests and discovery to later empire might be described as one of the notable features of legal history. This legal system crossed mighty oceans, traversed inhospitable terrain and reached tiny islands, miles from their nearest neighbours. Like the intrepid sea-voyaging people of the South Seas in their great canoes, the common law, carried by settlers, colonial administrators and in some respects by proselytising missionaries, reached distant shores. ${ }^{1}$ In the period prior to 1960 , Britain, either directly or through its larger overseas territories - notably Australia and New Zealand - had considerable influence in the south-west Pacific region and in particular over many small scattered island countries which were often the political pawns in power struggles between Britain, France, Germany and later Japan. The history of British colonial rule in the south-western Pacific, which commenced in the mid-1870s, ${ }^{2}$ has been covered elsewhere and is not the focus of this paper, ${ }^{3}$ which is concerned with the legal legacy of that rule in the island states of the region.

The paper first outlines the legal environment found in the region on the eve of independence and the consequences of this as island states moved into a new era. Then, focusing primarily on the area of family law, the paper considers the continuing relevance of the colonial legacy and its contribution to contemporary law through judicial intervention. Finally, the paper considers whether local law reform initiatives and the globalisation of laws are evidence of new forms of colonialism, especially legal colonialism, and the relationship between these more recent developments and previous interventions.

1 Missionaries, along with beachcombers and deserting sailors, were often the first non-indigenous contact for South Sea islanders once islands had been initially discovered, and the former were often the first to attempt settlement on the islands, bringing with them not only Christianity but also the values derived from, and which in many cases informed, the common law.

2 Much of the region was discovered earlier in the 1770 s by James Cook during his voyages in the region. British rule began in 1874 when Fiji was ceded to Britain and became a crown colony. Others followed, for example, Solomon Islands became a protectorate in 1893. Only Tonga was never administered by Britain, although for a time it was a protectorate (1900-70).

3 See, eg, R Louis and J M Brown (eds), The Oxford History of the British Empire, vol 4, 'The Twentieth Century' (OUP 2001); M Ntumy, South Pacific Island Legal Systems (University of Hawaii Press 1993); K Roberts-Wray, Commonwealth and Colonial Laws (Stevens \& Son 1966); J Dupont, The Common Law Abroad: Constitutional and Legal Legacy of the British Empire (Hein 2001). 


\section{Law on the eve of independence}

Most of the countries in the Pacific region that came under the influence of the common law as a consequence of colonial encounters achieved independence as a result of the 'winds of change' policy of the 1960s and the United Nations' Declaration on the Granting of Independence to Colonial Countries and People. ${ }^{4}$ Nevertheless, the move from colonial governance, either as directly ruled colonies, protectorates, ${ }^{5}$ mandated trust territories, ${ }^{6}$ or indirectly governed colonies, ${ }^{7}$ took time. The first country to attain its independence was Samoa, in 1962; the last was Vanuatu, in $1980 .^{8}$

Under colonial governance British law was introduced in a variety of forms and by various means, but essentially included legislation as well as the principles of law and equity articulated in the decisions of the courts. ${ }^{9}$ In the common law tradition, settlers were also presumed to take their law with them. ${ }^{10}$ As the mode of acquisition of a British possession was influential in determining what laws were to apply, ${ }^{11}$ each Pacific island country experienced a slightly different reception, transplant or imposition of British laws with variable degrees of law-making powers conferred on local institutions, as well as internal law-making powers conferred on the governor or high commission of the territory. ${ }^{12}$ For example, where imperial enactments were made in the contemplation that they applied to certain colonies - either expressly or impliedly - then those colonies could not make laws which derogated from these imperial enactments. ${ }^{13}$ While law-making and the introduction of metropolitan laws may have been seen as a key to colonial control, in fact most

4 Resolution 1514 (XV), 14 December 1960. Some also changed their names either at independence or in the period leading up to it (Vanuatu was the New Hebrides) and others have changed their names since, eg, Western Samoa is now Samoa and Fiji is now Fiji Islands.

5 Eg, Kiribati (then the Gilbert Islands) was a British protectorate 1892-1916, then a British colony (Gilbert and Ellice Islands 1916-75), and then from 1975-1979 it was a separate British colony of Gilbert Islands.

6 Eg, Samoa was a League of Nations mandated territory of New Zealand 1919-45, and then a UN trusteeship of New Zealand 1945-62.

7 Nauru, eg, was administered by Australia.

8 Some have not yet attained self-government, eg, Pitcairn, or have limited self-government by choice, eg, Tokelau, and some have modified autonomy, with assistance in foreign affairs, when requested, still in colonial hands, as is the relationship between New Zealand and Cook Islands and Niue.

9 Primarily, this was the law from England and Wales but this is not always clearly stated. The Western Pacific (Courts) Order 1961 refers to the laws of England in force on 1 January 1961 (s 15), however, in the Fiji Independence Order 1970 there is reference to any laws of the UK Parliament (s 2(1) with reference to existing laws). It has also been suggested that in some texts 'English' is an adjective and could encompass other common law systems derived from that of England rather than just laws from England: D Paterson, 'The Application of the Common Law and Equity in Countries of the South Pacific' (1977) 21 Journal of Pacific Studies 1. For the extent of this reception, see J Corrin Care, 'Colonial Legacies? A Study of Received and Adopted Legislation Applying in the University of the South Pacific Region' (1977) 21 Journal of Pacific Studies 33; G Powles, 'The Common Law as a Source of Law in the South Pacific: Experiences in Western Polynesia' (1988) 10 University of Hawaii Law Journal 106; and for Vanuatu and Solomon Islands, K Brown, Reconciling Customary Law and Received Law in Melanesia (Charles Darwin Press 2005) 26-41.

10 As Blackstone stated: 'If an uninhabited country be di[s]covered and planted by Engli[s]h [s]ubjects, all the Engli[s]h laws then in being, which are the birthright of every [s]ubject, are immediately there in force', Commentaries on the Laws of England, vol 1, s IV, Classics of English Legal History in the Modern Era Series (Dissertations-G 1978) 108. See on this process Brown (n 9) 30-34.

11 A point made in Salmond on Jurisprudence (10th edn, Sweet \& Maxwell 1947) 511-22.

12 Governor in the case of colonies and high commissioner in other dependent territories: D Paterson, 'South Pacific Customary Law and Common Law: Their Interrelationship' (1995) Commonwealth Law Bulletin 660, 662.

13 It was not always clear what countries these were as the list of British Western Pacific Territories changed over time, eg, Cook Islands and Niue were only British Western Pacific Territories until 1902 and thereafter came under New Zealand, whereas Fiji, New Hebrides (now Vanuatu) and Tonga were British Western Pacific territories until 1952, and the Solomon Islands until 1974. 
introduced laws had limited impact on the private transactions of the indigenous population being directed primarily as ensuring the 'peace, order and good governance' of the territory, and of meeting the needs of settler communities and colonial administrators. Consequently, despite this potentially large-scale imposition of foreign laws during the period of colonial influence, in reality the lives of many indigenous people continued to be governed by customary laws and practices, modified in various ways by contact with missionaries and traders from the 1830 s onwards, and later by colonial administration. ${ }^{14}$ Unwritten customary law which survived the colonial era, even if marginalised during it, became formally recognised as a source of law in many island countries and in some cases elevated in status, as former colonies moved towards nationhood. ${ }^{15}$

At independence, new Pacific island states acquired written constitutions - courtesy of the departing colonial administration, and were left with a confusing plurality of laws. ${ }^{16}$ Given the often very short period of transition from colonial administration to independence, interim strategies were incorporated into the new constitutions to provide that the laws in place would continue until replaced by national legislation made by the new legislative bodies. A typical example can be found in the Constitution of the Independent State of Samoa 1960:

(a) The existing law shall, until repealed by Act, continue in force on and after Independence Day;

(b) All rights, obligations and liabilities arising under the existing law shall continue to exist on and after Independence Day and shall be recognised, exercised and enforced accordingly; and

(c) Proceedings in respect of offences committed against the existing law may be instituted on and after Independence Day in that Court, established under the provisions of this Constitution, having the appropriate jurisdiction, and offenders shall be liable to the punishments provided by the existing law (s 114). ${ }^{17}$

The inclusion of such a provision was considered recently in Samoa in the case of Okesene $v$ Rossi [2010] WSCC 92, in which the continued application of the English law rule in Searle $v$ Wallbank was being debated. ${ }^{18}$

14 As pointed out by Paterson (n 12), customary law, although not often homogenous, was the 'common law' of Pacific island people, and, although purportedly the law of the people, like the English 'common law' tended to be articulated by a select few.

15 See G Powles, 'Common Law at Bay? The Scope and Status of Customary Law Regimes in the South Pacific' (1997) 21 Journal of Pacific Studies 61, although Paterson notes that this did not occur in Tonga, Niue or Cook Islands (n 12) 664.

16 On the diverse forms of legislation giving effect to independence, see J Corrin, 'Discarding Relics of the Past: Patriation of Laws in the South Pacific' (2009) 39(4) Victoria University of Wellington Law Review 635, 640.

17 See similarly, but with more complications because of its prior Anglo-French condominium rule, the 1980 Constitution of Vanuatu, art 95(1): 'Until otherwise provided by Parliament, all Joint Regulations and subsidiary legislation made thereunder in force immediately before the Day of Independence shall continue in operation on and after that day as if they had been made in pursuance of the Constitution and shall be construed with such adaptations as may be necessary to bring them into conformity with the Constitution. (2) Until otherwise provided by Parliament, the British and French laws in force or applied in Vanuatu immediately before the Day of Independence shall on and after that day continue to apply to the extent that they are not expressly revoked or incompatible with the independent status of Vanuatu and wherever possible taking due account of custom.' On problems in interpreting what this latter clause means, see Corrin (n 16).

18 The rule in Searle v Wallbank [1947] AC 341 (HL) was that an owner or occupier of land adjacent to a highway had no legal obligation to highway users to maintain his hedges and gates so as to prevent his animals from straying on to the highway. This remains good law in Samoa because Parliament has not stated otherwise, although the tort of negligence will usually provide a remedy. 


\section{The court stated:}

The framers of the Constitution obviously understood that our law as a newly independent nation would not be comprehensive and cover every situation. To fill any vacuum they provided for English common law and equity to apply until such time as local law could be brought to bear on the matter. As explained by Dr Aikman as constitutional adviser to the 1960 Constitutional Convention Debates (see Part III Constitutional Convention Debates (Samoan Language) 01 October 1960-28 October 1960 at page 1252) when speaking about article 111 and the definition of 'law':

'Article 111, definition of the word "law" - you haven't got enough law to cover all the kinds of situations which will arise. You need some sort of reservoir of law when you strike a new and unusual case. Now the reservoir to which you will have to go in Samoa for many years to come, is going to continue to be the Common Law and equity as those have been developed particularly in the Courts in England . . . This particular definition of law has a most fundamental importance from the point of view of the future law of Western Samoa and therefore, I felt that it was my duty to explain it to you in the detail I have used.' (para 20)

What was included in this 'existing law' varied from country to country depending on what sources of law had originally applied;19 what 'cut-off' date was specified;20 and how the legislation retaining introduced law was phrased. ${ }^{21}$ This in turn could be different for different sources of law. UK laws having effect in any country of the region included Westminster laws extended specifically to have effect either on certain areas of law or in

19 Eg, in Samoa prior to independence a wide range of laws applied including: the New Zealand Samoa Act 1921 and its amendments; decrees made by the German Government 1900-1919 until their repeal in 1972; ordinances made by the New Zealand administrator with the advice and consent of the Western Samoan Legislative Council, 1919-1947, and thereafter ordinances made by the Western Samoan Legislative Assembly with the assent of the New Zealand high commissioner 1947-1962; Acts of the New Zealand Parliament that were enacted for Western Samoa; Acts of the British Parliament that were in force in England on 14 January 1840, provided they were in force in New Zealand on 7 December 1921 and provided they were not inconsistent with the Samoa Act or any ordinance or regulation in force in Western Samoa, and not inappropriate to the circumstances of Western Samoa (Samoa Act 1921 (NZ), s 349); subsidiary legislation made under any of the above legislation; English common law and equity except so far as inconsistent with legislation or subsidiary legislation in force in Western Samoa or inappropriate to the circumstances of the country (Samoa Act 1921 (NZ), s 349); and custom for the purpose of ascertaining the rights to customary titles and land (Samoa Act 1921 (NZ), s 278); Samoan Land and Titles Ordinance 1934, s 37; and for the purpose of determining the validity of marriages prior to 1921 (Samoa Act 1921 (NZ), s 372): D Paterson, 'Sources of Law Information: Samoa' (2001) <www.paclii.org/ws/sources.html> accessed 14 August 2012. See, more extensively, J Corrin and D Patterson, Introduction to South Pacific Law (3rd edn, Palgrave Macmillan 2011).

20 This is the date after which introduced laws no longer applied. For many this is the date of independence but for some it is before this. See, eg, Samoa above and the article by Corrin Care (n 9), and J Corrin, 'Cultures in Conflict: The Role of the Common Law in the South Pacific' (2002) 6(2) Journal of South Pacific Law <www.paclii.org/journals/fJSPL/vol06/2.shtml> accessed 14 August 2012.

21 See Powles (n 9), and Corrin (n 20). 
respect of British subjects abroad, ${ }^{22}$ laws made under orders in council or proclamations, ${ }^{23}$ regulations and ordinances, ${ }^{24}$ and laws deemed to be of 'general application'. ${ }^{25}$

This last has caused some difficulty. According to Roberts-Wray, a statute of 'general application' is one 'of general relevance to the conditions of other countries and, in particular, not based upon politics or circumstances peculiar to England'. ${ }^{26}$ Roberts-Wray expressed the opinion that the phrase 'statutes of general application' would probably be unacceptable today because of its lack of definition, but goes on to claim, nevertheless, 'it does not appear to have given the courts serious trouble', a view cited quite recently with approval by Lord Hope with reference to Pitcairn Islands. ${ }^{27}$ In fact the question of whether a statute is one of general application or not has troubled the courts in the South Pacific region for some time. ${ }^{28}$ Certainly, courts in the region have not been consistent in their understanding or interpretation of the phrase, to the extent that an English Act of Parliament may be held to be of general application in one Pacific island country and not in another, ${ }^{29}$ or different approaches may be adopted by different judges in the same jurisdiction.

For example, in 2007, two different judges sitting at different times but in the same court in the Solomon Islands held different views on the Adoption Act (UK) 1958. In the case of Re Noeleen Aba Miria (an infant), ${ }^{30}$ the judge held that the Act was one of general application in force on 1 January 1961 (the cut-off date for statutes of general application in Solomon Islands) and therefore applied in Solomon Islands. In support of this conclusion the court found that the application of the Act was not limited solely to England and Wales but extended to Scotland (at the time); applied to applications for adoption by persons not normally resident in Great Britain; and concerned matters not peculiar or specific to the UK but of universal application. It was also held that there were no local circumstances that made the application of the Act inappropriate. In contrast, and in the same year, a different judge held that:

The Act is wholly irrelevant and should be left to those resident in the United Kingdom, and to those conversant with the law appertaining to adoptions in that foreign jurisdiction with its peculiar incidents. There is no evidence of any proclamation, for instance that an adoption order made in this country will conclusively be presumed to comply with that law . . . I accordingly am not satisfied that the United Kingdom legislation has such extra territorial

22 See, eg, the extension of the Fugitive Offenders Act 1967 (UK); Nuclear Installations Act 1965 (UK); Civil Aviation (Investigation of Accidents) Regulation 1965 and the Emergency Powers Order in Council 1939 in Kiribati.

23 Eg, the Western Pacific Order in Council 1877, the Pacific Order in Council 1893, the Western Pacific (Courts) Order 1961 and the Western Pacific (Appeals to the Privy Council) Order 1970.

24 Eg, Queen's (King's) Regulations made by the high commissioner of the Western Pacific, 1893-1916 (Pacific Order in Council 1893, s 108); ordinances made by the high commissioner of the Western Pacific; the resident commissioner or the governor, if there was one, and any subsidiary legislation made under the above.

25 As provided for under Western Pacific (Courts) Order 1961, s 15.

26 Roberts-Wray (n 3) 556.

27 Christian and Others $v$ The Queen [2006] PNPC 1; [2006] UKPC 47 [76] (Lord Hope quoting Roberts-Wray (n 3) 545). See, however, discussion on the problems caused by this phrase in Corrin Care ( $\mathrm{n}$ 9) and the inconsistencies in interpretation found in the region.

28 See Corrin Care (n 9) and D K Srivasta and D Roebuck, 'The Reception of the Common Law and Equity in Papua New Guinea: The Problem of the Cut-Off Date' (1985) International \& Comparative Law Quarterly 850 .

29 Cf, eg, Freddy Harrisen v John Patrick. Holloway (1980-1988) 1 VLR 147 (a Vanuatu case) with Indian Printing and Publishing Co v Police (1932) 3 Fiji LR 142 (a Fiji case). See also in respect of the criminal law in Pitcairn, A Angelo and F Wright, 'Pitcairn: Sunset on the Empire?' (2004) New Zealand Law Journal 431.

30 [2007] SBHC 138. 
effect as to require Solomon Islanders domiciled and resident in this country to seek to fit within its culture, administration and regime. By virtue of clause 1 to this Schedule 3 of the Constitution, I find that the Adoption Act 1958 (UK) is not of general application so as to have effect as part of the laws of Solomon Islands. ${ }^{31}$

This caveat of compatibility with 'local circumstances' which would allow a court to exclude the application of introduced laws appears to be one that has seldom been used despite the very different cultural and social circumstances found in Pacific island countries. ${ }^{32}$

Although, gradually, Pacific island states are replacing laws left in place at the date of independence with those passed by national parliaments, many of these new laws appear to be modelled on legislation drawn from other common law jurisdictions, or to retain reference to previously introduced foreign law, or to marginally modify existing introduced law to make it appear more 'home-grown'. There are also challenges to this process of 'patriation' of laws, ${ }^{33}$ especially where there are practical constraints on how far the law in any area can be rewritten 'from scratch', and ideological constraints on the extent to which patriation - as a deliberate sovereign act, may mark formal (if selective) acceptance of 'foreign' legal transplants. ${ }^{34}$ Even if legislation is patriated or the extent of the application of introduced law is curtailed, for example, through a process of review and rationalisation, ${ }^{35}$ abolition, ${ }^{36}$ or limitation, there are further considerations. First, where there is only partial exclusion of English law this may result in legal lacunae. For example, in Tonga under the Civil Law Act 1966, English common law (statutes and general principles of common law and equity) was widely applicable. ${ }^{37}$ In 2003 all reference to English statutes was abolished by an amendment to the Act, so that now under the Civil Law (Amendment) Act only 'the common law of England and the rules of equity' apply in Tonga. As a result there are areas where presently there is no legislation because previously applicable English law has been excluded and no new laws have been put in place by the Tongan legislature. Second, dealing with legislation only partially addresses the issue of the colonial legal legacy. There is still the question of the general principles of common law and equity derived from the decisions of courts outside the Pacific. It is here, in particular, that the continuing influence of English judges and counsel endures.

In making provision for interim legal regimes, the independence documents of Pacific island countries included a variety of approaches to caselaw as a source of law. ${ }^{38}$ Where a 'cut-off' date for general principles of common law and equity was given (or these were

31 Re Tiokobule Bero (an infant) [2007] SBHC 94, Brown J. Solomon Islands now has national legislation, the Adoption Act 2004, which came into effect in 2008, so the problem may in future be avoided.

32 See critical comment by B Narokobi, 'Adaptation of Western Law in Papua New Guinea' (1977) 5 Melanesian Law Journal 52.

33 This is a term used by Corrin ( $\mathrm{n}$ 16). Examples can be found in Niue and Tokelau.

34 It is perhaps notable that the two countries where this has been undertaken, Tokelau and Niue, have relatively small populations (although geographically dispersed), which may have facilitated the democratic discussion necessary for the creation of truly autochthonous law and aid funding from New Zealand to support the project.

35 See, eg, in New Zealand the Imperial Laws Act 1988, and s 8 of the Repeal of Statutes Act 1972 (Samoa).

36 Eg, in Niue by the Interpretation Act 2004 and in Tokelau by the Repeal of Laws Rules 1997.

37 Pt 3: "the Court shall apply the common law of England and the rules of equity, together with statutes of general application in force in England'.

38 See, eg, in Nauru under the Custom and Adopted Laws Act 1971 it is clearly stated in s 4(2): 'The principles and rules of equity which were in force in England on the thirty-first day of January, 1968, are hereby adopted as the principles and rules of equity in Nauru'; whereas the 1965 Constitution of Cook Islands is much less specific, stating only that subject to constitutional provisions: 'The existing law shall, until repealed, and subject to any amendment thereof, continue in force on and after Constitution Day', s 77(a). 
included in the more generic term 'English law' or 'common law') then subsequent caselaw of the English courts was in principle inapplicable. ${ }^{39}$ However, the door was left open for subsequent developments in common law caselaw to reach the Pacific in a number of ways. First, via the Privy Council (where appeals to that court were retained) and the body of Commonwealth jurisprudence developed by the Privy Council. Secondly, while there may have been a cut-off date for English caselaw, this did not apply to the persuasive influence of decisions from other common law jurisdictions, such as Australia, New Zealand and the USA, so that reference to these might also incorporate cross-reference to later English court decisions. ${ }^{40}$ Third, where English law 'statutes of general application' or other English laws extended to the colonies were retained, caselaw interpreting this legislation might still be referred to, and when novel cases arose in Pacific island jurisdictions and there was little local or regional caselaw to refer to, this was likely to happen especially where lawyers and judges themselves were more familiar with the jurisprudence from elsewhere.

There is, however, and arguably always has been, discretion given to the courts to be selective in the application of the general principles. For example, under colonial rule general principles were only applicable in so far as they were compatible with local circumstances, or were directed at specific purposes - for example, the peace, order and good governance of the colony or protectorate. Since independence, this discretion has been restrained in a number of ways, for instance: there may be restrictions regarding compatibility with the constitution or other legislation; ${ }^{41}$ or sources of law may be specifically ranked; 42 or the application of these principles may be subject to a caveat, such as taking into account customary law or traditional values wherever possible; ${ }^{43}$ or certain areas of law or subject matter may be stated to be governed by customary law only; ${ }^{44}$ or reserved for customary courts and tribunals applying customary law. ${ }^{45}$ Consequently, the reception, adoption, adaptation and continuing application of general principles of common law and equity as developed through the courts, can be selective and, while Pacific judges in the common law tradition do not 'make' the law, they can certainly shape it.

\section{The consequences of the colonial legacy for family law}

The relevance and retention of introduced laws in the contemporary island Pacific is reflected in many areas of family law. This is an area which is particularly apt for consideration because, firstly, it is where one might expect personal/customary local laws to be strongest; secondly, it is an area where the context and environment of introduced laws might make them less likely to be laws of 'general application' - being specific to the social/familial time and place in which they are made; thirdly, because it is an area where national governments post-independence have been slow to act so that the 'interim' legal

39 It is not always clear if the same cut-off date for legislation or statute law applies to the general principles or not. See comment by Powles (n 9).

40 Also, if the cut-off date referred to 'the common law' without the adjective 'English' or 'British' or made reference to 'Britain', it could be argued that there was nothing to prevent courts from looking at the persuasive authority of other common law jurisdictions.

41 See, eg, Solomon Islands Constitution, s 5, which was brought into effect by SI 1978/783 and Constitution of Tuvalu, sch 5 , s 2 .

42 See, eg, the definition of 'law' in Samoa Constitution 1960, s 111.

43 See, eg, Constitution of Vanuatu, s 95(2).

44 See Paterson (n 12).

45 Even here the common law may be influential either because the subject matter raises concerns which transcend the boundary between customary and other law, eg, leases of customary land, or because there is appeal from the customary tribunals to a non-customary one, or because the matter raises human/fundamental rights issues which may also be affected by international treaty obligations (see below). 
regime has often persisted unchallenged and judges have been confronted with the task of applying often outdated introduced laws - or national laws closely modelled on these, in the face of changing and sometimes conflicting normative orders. The dilemma can be illustrated by considering cases of guardianship, adoption and the allocation of matrimonial property on divorce.

\section{GUARDIANSHIP}

Throughout the region children are often cared for by other family members, for instance, in cases such as the death or absence of one or both parents, for purposes of schooling, in fulfilment of family obligations, or to take advantage of the diverse resources and members of the extended family. While these arrangements are frequently regulated by custom, it is often unclear what formal guardianship laws apply. For example, in Vanuatu, there is no domestic legislation on this matter. The law in force at the date of independence would include the Guardianship of Minors Act (UK) 1971,46 as well as the French law in force at that date. ${ }^{47}$ Whether such laws were of 'general application', however, is uncertain due to the specificity of the forms and structures, including jurisdiction of the courts, in their respective countries of origin. Similarly, in Fiji in the case of Lakhan v Lata [1994] FJHC 26, the court discovered that there was no law in Fiji that actually provided for the appointment of a guardian for an orphan. However, the court held that it had similar power to that of the English courts' parens patriae and cited with approval Lord Brandon's dicta in Re F [1990] AC 1 where he explained:

This is an ancient prerogative jurisdiction of the Crown going back as far perhaps as the 13th Century. Under it the Crown as parens patriae had both the power and the duty to protect the persons and property of those unable to do so for themselves, a category which included both minors (formerly described as infants) and persons of unsound mind (formerly described as lunatics or idiots). [57]

and Lord Denning's dicta in Re L (an infant) [1968] PD 119, 156, referring to the inherent jurisdiction of the Court of Chancery in relation to infants. ${ }^{48}$ As s 18 of the Fiji High Court Act (Cap 13) (formerly the Supreme Court) expressly gave the Supreme Court (ie High Court) 'all the jurisdiction, powers and authorities which are for the time being vested in or capable of being exercised by Her Majesty's High Court of Justice in England', Lord Denning's dicta that 'If a question arises as to the welfare of a child before any judge of the High Court, he can make such order as may be appropriate in the circumstances' was accepted. Although, the indigenous judge, Justice Fatiaki, found this state of affairs highly unsatisfactory, and expressed the view that:

as we approach the 21 st century it is wholly unsatisfactory that this court should have to resort to antiquated (even 'arcane') 'sources of the law' to find its jurisdiction to deal with infants. Furthermore in a young population such as ours where a very large proportion of the population is under the age of 21 years the absence of any specific legislation in this area represents a serious lacuna in our statute books. ${ }^{49}$

46 As acknowledged in Re Chelsea Lea [2000] VUSC 22 and, probably by implication, the amending Act, the Guardianship Act (UK) 1973.

47 Arts 389-476 Code Civil and Loi n 70-459. For comment, see S Farran, A Digest of Family Law in Vanuatu (University of the South Pacific Law School Monographs 2003), 36-38.

48 The English law principle of parens patriae has also been applied in Tonga in Re Tevita [2000] TOSC 22.

49 Original emphasis. 
Nevertheless, reference to English law (and Lord Denning's dicta in Re L (above)) in this area continues, and Lakhan v Lata was cited with approval in Nai v Cava [2008] FJHC 274.50

Although in some countries of the region 'arcane' English law has been replaced, as, for example, in Tonga, 51 and in others it has been held that introduced law has no application to native and part-native children so that matters of guardianship are to be solely determined by reference to customary law, ${ }^{52}$ the residual legacy of colonial law can place courts in the position of having to weigh introduced law and customary law and there may be a conflict. In the Solomon Island case of $K v T$ and KU [1985] SBMC 2, it was held that, even though custom more usually governed adoption and guardianship, the UK Guardianship of Infants Act 1925 still applied because it had not been replaced by Solomon Islands legislation, and the applicable principles were those developed in English courts, notably:

The concept of the interest of the child being paramount in guardianship or custody cases has been with lawyers and courts in the UK for a long time. It has become a statutory creature. The Guardianship of Infants Act 1886 section 5 'the Court may ... make such order as it may think fit regarding the custody of such infant ... having regard to the welfare of the infant ...'. It was in the Guardianship of Infants Act 1925 section 1 that the words used by all courts today first appeared 'the Court ... shall regard the welfare of the infant as the first and paramount consideration'. ${ }^{53}$

In some respects this reliance on the English law gives courts the opportunity to apply the law in a way that reflects contemporary mores, even if these are not necessarily local, as will be seen regarding judicial incorporation of the UN Convention on the Rights of the Child (UNCRC).

\section{ADOPTION}

As with guardianship, adoption is frequently governed by customary laws and practices so that many adoptions occur outside the formal system. In Solomon Islands and Marshall Islands there have been recent efforts to enact new national legislation and in Samoa to reform existing law. Elsewhere, however, formal law on adoption remains that introduced from England or closely modelled on it. ${ }^{54}$ This legacy is a mixed blessing. On the one hand, it provides certain procedural safeguards: for example, minimum ages for prospective adoptive parents; requirements of consent from the birth parent(s); sufficient differences in age between the child being considered for adoption and the adoptive parents; and certain protections for the child. On the other hand, most of the formal law reflects a period in which the rights of the legitimate child and his/her parents were very different from those of the illegitimate child and his/her parents - especially the father - and the supporting framework in which the law was designed to operate was very much that of the developed world in which the expertise of various educational and social services personnel was

50 Nor does guardianship appear to have been addressed by the Family Law Act 2003 (Fiji).

51 Guardianship Act 2004.

52 Eg, in Papua New Guinea, where the Infants Act 1965 was introduced, this was held to be inapplicable in Sannga, Deceased; Timereke v Ferrie and Johns [1983] PNGLR 143 and ignored in subsequent cases.

53 The applicability of English principles was accepted in later cases such as Tavake v Tavake [1998] SBHC 118, although here it was also noted that: 'How the courts in England have interpreted the Acts of general application in this area of the law is useful as a guide. This is however not to say that cases in Papua New Guinea, Australia, New Zealand and within the region are less relevant.'; per Kabui J.

54 Eg, the Adoption Act 1955 (NZ) (Niue); Children Act (UK) 1975 (Kiribati); Adoption of Children Ordinance 1965-1967 (Nauru); Adoption Act (UK) 1958 (Vanuatu); Infants Ordinance 1961 (Samoa modelled on the Adoption Act (NZ) 1955, read with the Infants (Adoption) Regulations 2006); Adoption of Infants Act 1945 (Fiji). 
available to the court in arriving at a decision which was in the best interests of the child and in which there was state welfare available for unwanted children. This presents a challenge for judges in a region where this framework is frequently not available. If judges stick to the letter of the law, then applications to adopt may fail. If they adopt a more liberal approach, the adoption may be granted, but in either case the welfare or best interests of the child may not always prevail.

The dilemma is illustrated by the caselaw. In the Tongan case of Re Whyte and Whyte [1993] TOSC 5, the applicant parent was the New Zealand husband of the mother of six illegitimate children residing in Tonga at the time of the application. He had a criminal record, an acknowledged drinking problem and had spent very little time bonding with the children prior to the application. If the application were to be granted the children would be removed from Tonga and live with their mother and her new husband in New Zealand. The New Zealand social welfare officer did not approve of the adoption. Nevertheless, the Tongan court approved the application, believing the adoption and the relocation of the children to be in their best interests even though this would mean uprooting them and probably subjecting the new relationship to considerable strain.

By contrast, in the Fiji case of Social Welfare Officer v Marshall [2008] FJHC 283, an adoption order granted by a magistrate was overturned on appeal on the grounds that the applicants were not resident in Fiji and therefore failed to comply with the mandatory residence requirement of s 6(4) of the Adoption of Infants Act 1945 (legislation passed under colonial administration), despite the fact that there was evidence that the prospective parents could offer the two children a good home together. Here, the judge held that 'Whilst I have much sympathy for the position that Mr and Mrs Marshall now find themselves and for the infants, it is the function of the courts only to interpret the law and not to amend it. ${ }^{55}$

Adopting a flexible approach, however, can lead to inconsistent decisions. For example, in the Samoan case of $S \& M v$ District Court, Apia [2000] WSSC 42, the court had to decide if it had jurisdiction to consider an application for adoption of an illegitimate baby born outside Samoa. Now married, the child's mother and her husband wished to adopt the baby. Seeking to resolve the matter, the judge referred to the jurisdiction of the English courts in which the making of an adoption order was not dependent upon the domicile of the child to be adopted. Dicey and Morris on The Conflict of Laws and Cheshire and North's Private International Law ${ }^{56}$ were cited with approval. ${ }^{57}$ The court concluded that as neither English law nor New Zealand law made residence a requirement for adoption, Samoa would similarly not require it, despite a decision the year before that residence was required. ${ }^{58}$

While the formal laws represent only a partial picture of adoption in the region, ${ }^{59}$ the way in which judges use this common law legacy is informative. Although there is the justifiable claim that much of the formal law suffers from many 'archaic' characteristics, nevertheless, it appears to offer sufficient scope to judges who are prepared to adopt comparative or pro-active approaches to interpretation to meet the contemporary needs of

55 This was also an inter-country adoption and even if the legislation had been amended the order may not have been granted.

56 L Collins (ed), Dicey and Morris: The Conflict of Laws (12th edn, Sweet \& Maxwell 1993) 886; G C Cheshire and P M North (eds), Private International Law (12th edn, Butterworths 1992) 760.

57 Reference was also made to New Zealand law and Butterworths Family Law in New Zealand (6th edn, Butterworths 1993) 721-30.

58 Re Application for Adoption by Solomona [1999] WSDC 1.

59 Because forms of customary adoption also exist and may be widely practised in a number of countries and there are also restrictions on who can adopt or be adopted, eg, in Tonga only illegitimate children can be adopted, while in Nauru a Nauruan child can only be adopted by a Nauruan if his/her spouse is also Nauruan. 
litigants, suggesting that, although the law may appear to be 'frozen in time', in practice this is not always the case.

\section{MATRIMONIAL PROPERTY}

It is not just in laws pertaining to guardianship and adoption that this might be claimed. While it may be thought that disputes over matrimonial property in a region of underdeveloped and developing economies are rare, increasingly people are acquiring more disposable wealth and more material assets. Generally, the courts cannot exercise divorce jurisdiction over land held under customary tenure, but can determine the allocation of other forms of wealth that are considered to be matrimonial property. Where there is legislation relating to matrimonial property allocation ancillary to divorce, then the courts have considerable discretion as to how that allocation is made and in exercising this almost invariably, but not always, refer to English law precedents. Some countries, however, have gaps in their law on this matter. In Vanuatu, for example, although there is national legislation - the Matrimonial Causes Act 1986 (Cap 61), it failed to provide for matrimonial property issues, so the English Matrimonial Causes Act 1973 applies as a statute of general application in force at the date of independence in $1980 .{ }^{60}$ In the case of Hanghangkon $v$ Hanghangkon [2010] VUSC 117, the Supreme Court referred to s 25 (1)(f) of the 1973 (UK) Act with particular approval as this allowed the court to take into account 'the contributions made by each of the parties to the welfare of this family, including contributions made by looking after the home or caring for the family'. In the context of the Pacific, where society is still very patriarchal and where women are still predominantly the homemakers and men the wage earners, this English law enabled the court to take a non-gendered perspective of contribution by each spouse, which, while it may have offended traditional family ordering, gave effect to non-discrimination provisions in the constitution and Vanuatu's obligations under the Convention on the Elimination of all forms of Discrimination against Women.

In Vanuatu the courts have not gone so far as to accept the presumption of joint ownership of all matrimonial assets. ${ }^{61}$ In Samoa, however, where, until recently, there has been no statutory provision governing the allocation of matrimonial property on divorce, the court has followed the very latest in English law thinking on this, adopting the 'yardstick of equality' for the division of matrimonial property, and demonstrating very clearly a preference for the English authorities that confer a wide statutory discretion on the courts to deal with matrimonial properties, rather than the more detailed statutory provisions found, for example, in New Zealand legislation. ${ }^{62}$

Although the formal law only presents a partial picture, the topics of guardianship, adoption and matrimonial property illustrate a combination of factors which foster the continuing relevance of English law in the region: lack of national legislation to replace colonial legislation, jurisdictional approaches shaped by English law, and contemporary references to English law decisions.

It is through these latter in particular that English judges have continued to hold authority in the region: notably in the area of equity.

60 For explanation, see S Farran 'The Joli Way to Resolving Legal Problems: A New Vanuatu Approach?’ (2004) 1 Journal of South Pacific Law <www.vanuatu.usp.ac.fj/jspl> accessed 1 September 2012. For criticism of this approach, see Brown (n 9) 132-40.

61 Joli v Joli [2003] VUCA 27.

62 Arp v Arp [2008] WSSC 35. This approach has now been incorporated by an amendment in late 2010 into the Divorce and Matrimonial Causes Act 1961, ss 22B and 22C. 


\section{EQUITABLE INTERVENTION IN FAMILY LAW}

It is evident from a number of cases considered by the courts of the region that general equitable principles remain important in family matters, especially where there is a gap or inadequate provision in the written law, whether that written law is introduced 'imperial' law or national legislation. ${ }^{63}$ As indicated, reference to a residual source of law, described as 'the general principles of English common law', ${ }^{64}$ is taken to include the principles of equity. These principles can be of significance in deciding family cases especially where there is little alternative law to fall back on, for example, where there is a dispute among family members over property that does not fall under matrimonial legislation, ${ }^{65}$ or where there is no provision in that legislation for the division of property ancillary to divorce. ${ }^{66}$ For instance, in the Samoan case of Elisara v Elisara [1994] WSCC 14, the court held that:

The common law principles which have been developed and applied by the courts to de facto unions really have their origin in English authorities where the House of Lords dealt with matrimonial property disputes between married couples applying common law principles.

Focusing on the use of the constructive trust, the court considered: the reasonable expectation test, developed and advocated in New Zealand; ${ }^{67}$ the unconscionable conduct test favoured in Australia; ${ }^{68}$ the unjust enrichment test advocated in Canada; ${ }^{69}$ the principles of estoppel, which have found some favour in England and other common law jurisdictions; ${ }^{70}$ and the test of common intention combined with detriment found in leading English cases. ${ }^{71}$ Considering the choice of common law precedents, the Samoan Supreme Court elected to follow a combined test of unjust enrichment and reasonable expectation, on the grounds that the first had been applied in Canada to property disputes between de facto and married couples, while the second had been applied in de facto disputes or in situations where there was no matrimonial property legislation. ${ }^{72}$ Although several years later in Arp v Arp [2008] WSCC 35 it was recognised that 'Since the decision in Elisara v Elisara [1994] WSSC 14, there have been significant developments in England in the area of matrimonial property', the Samoan judge was still 'of the respectful view that they provide relevant principles which may be used to guide the approach to be taken by the Samoan courts to the resolution of applications for ancillary relief in, or following, a

63 For a comprehensive overview, see Paterson (n 9).

64 Or words to similar effect, see, eg, the Constitution of Solomon Islands 1978, which states: '[T] he principles and rules of the common law and equity shall have effect as part of the law of the Solomon Islands.' (para 2 of $\operatorname{sch} 3)$.

65 See, eg, Lafaele $v$ Vito [2001] WSSC 2 and Maharaj v Chand [1986] FJ-UKPC 5.

66 A legal state of affairs still found in Vanuatu and Tonga.

67 Hayward v Giordani [1983] 1 NZLR 140; Pasi v Kamana [1986] 1 NZLR 603; Oliver v Bradley [1987] 1 NZLR 586; Gillies v Keogh [1989] 2 NZLR 327.

68 Muschinski v Dodds [1985] 160 CLR 583; Baumgarter v Baumgarter [1987] 164 CLR 137.

69 Murdoch v Murdoch [1975] 1 SCR 423; Rathwell v Rathwell [1978] 2 SCR 436; Pettkus v Becker [1980] 2 SCR 834; Sorochan $v$ Sorochan [1986] 2 SCR 38.

70 Grant v Edwards [1986] 2 All ER 426 (obiter per Sir Nicholas Browne-Wilkinson, 439); Gillies v Keogh (n 67).

71 Pettit v Pettit [1970] AC 777; Gissing v Gissing [1971] AC 886; Grant v Edwards (n 70); Lloyds Bank. v Rosset [1990] 1 All ER 111 (HC). For comment on this judicial approach, see S Farran, 'Palm Tree Justice? The Role of Comparative Law in the South Pacific' (2009) 58 International \& Comparative Law Quarterly 181.

72 In the end the court did not award the wife any interest in the matrimonial home after applying the unjust enrichment and reasonable expectations tests to this case. 
petition for dissolution of marriage' ${ }^{73}$ He went on to refer to the more recent English cases of Miller v Miller [2006] UKHL 24 and White $v$ White [2000] UKHL $54 .{ }^{74}$

As development brings more disposable wealth to Pacific islanders, the role of the trust, especially the constructive trust, in the resolution of property disputes on the breakdown of relationships may be increasingly important and, alongside this, continuing reference to English authorities, ${ }^{75}$ including reference to the judgments of specific judges. Those who feature prominently include Lord Mansfield, Lords Reid, Diplock and Denning and Sir Nicholas Browne Wilkinson, Lord Nicholls and Baroness Hale, and, in citing their judgments, little critical distinction is made in Pacific courts between the context in which these judges sit and those of the Pacific bench. One reason for this may be that, besides the substantive law of Pacific islands being strongly influenced by British law, the approach of judges and the procedures of the court are predominantly those of the common law. Although there are some differences, for example, single judgments from Court of Appeal benches composed of more than one judge, a more limited range of authorities referred to and, occasionally, instances where the bench has had to assist the Bar or reprimand members of it, these are largely due to constraints on resources, such as court libraries, time - especially where the bench is composed of visiting judges - lack of experience on the part of lawyers appearing in court, or unrepresented litigants. Referring to the 'strength and uniformity of the common law judicial tradition', Sir Anthony Mason, who sat on benches in Australia, Hong Kong, Solomon Islands and Fiji, suggested that this is evidenced by:

The sense of responsibility, the sense of independence and objectivity, the need to identify the issues and to ascertain the strength and the weakness of each party's case and to deal with the issues in a judgment which fully exhibits the reasons for the decision. ${ }^{76}$

While the full exhibition of reasons is not always apparent from reported judgments, this judicial tradition is one encountered throughout the region, particularly in the higher courts.

\section{Law reform, internationalism and neocolonialism}

Although young in post-colonial terms, Pacific island states, their governments and people are experiencing the pressures of rapid social and economic change, both from within and beyond their boundaries. Initially this shifted the emphasis for post-colonial states to issues of economic development rather than law reform. ${ }^{77}$ More recently, however, there has been some agitation to engage with law reform and to put in place laws and mechanisms which

73 The willingness of the Samoan courts to resort to principles of equity in these situations can be contrasted sharply with that of the Tongan courts where, although the general principles of equity are still applicable, they are not applied: see Halapua $v$ Tonga [2004] TOCA 5.

74 The choice of English legal authorities in Arpv Arp (n 62) has been upheld in Hadley v Hadley [2010] WSSC 6, which also follows English authorities decided prior to 2010, on the question of pre-nuptial contracts. Whether Samoan courts will follow English courts in a change of approach on this topic remains to be seen.

75 See, eg, in Papua New Guinea, Kisekolv Kisekol (No 2) [2009] PGNC 192; in Vanuatu, Michell v Michell \& Togase [2001] VUSC 71; in Solomon Islands, Goodhew v Goodhew [2007] SBHC 140.

76 Hon Sir Anthony Mason, 'The Common Law in Final Courts of Appeal Outside Britain' (2004) 78 Australian Law Journal 183, 185.

77 D Weisbrot, 'Papua New Guinea's Indigenous Jurisprudence and the Legacy of Colonialism' (1988) 10 University of Hawaii Law Journal 1, 3. 
meet the development agenda. ${ }^{78}$ Although this is less so in the field of family law than, for example, banking, terrorism or trade, there are expectations raised by organisations ranging from Save the Children to the reporting committees of various UN conventions that laws will be reformed or initiated to meet international obligations and satisfy domestic demands. Invariably this means that funding has to be found and experts engaged. Often both come from donor states or organisations, for example, from Australia, New Zealand, Canada, the European Union and international bodies such as UNICEF. ${ }^{79}$ This inevitably has an impact on the end product. In particular it raises questions about modern legal transplants where new laws and institutions are closely modelled on those from elsewhere or drafted by those coming from different socio-economic backgrounds albeit from common law jurisdictions, ${ }^{80}$ and about the sustainability of such reforms once the experts and overseas advisers have left. In the context of family law, one example will be chosen: the Family Law Act 2003 from Fiji. 81

The Act marked the culmination of a movement towards reform and consolidation of the law which commenced in $1998 .{ }^{82}$ As with other Pacific countries which came under the influence of British colonial administration, Fijis family law system was marked by a collection of inherited legislation or national legislation modelled on English laws and a system of courts that took no account of the special needs of family litigants. ${ }^{83}$ After public consultations, the Family Law Bill was drawn up in 2002 and became law in 2003. The legislation incorporated major innovations in family law from a regional perspective. In particular it created the Family Court (a separate Division of the High Court and Magistrates Court) as a specialist court to deal with matters of divorce, maintenance, property division and children's issues. Intended to give effect to Fiji's obligations under the UNCRC, children and their welfare are a central feature of the Act, with an emphasis on the obligations of parents towards their children and procedures are directed at encouraging parents to come to agreements regarding the best interests of their children without litigation. ${ }^{84}$ There is provision for counselling and an emphasis on reconciliation aimed at preserving or saving a marriage, ${ }^{85}$ or, where this proves impossible, enabling the parties to terminate it as painlessly as possible. Plainly, although it is envisaged that these services will help the couple to stay married, the willingness to do so has to come from the spouses and in many situations the marriage may have irretrievably broken down. Where

78 There are, eg, Law Reform Commissions in Fiji, Solomon Islands and Papua New Guinea and recently those in Samoa and Vanuatu have been activated (after years of inaction). However, much of the work of these agencies is being done under the umbrella of the Australasian Law Reform Agencies and in Solomon Islands under the Australian-led Regional Assistance Mission to Solomon Islands (RAMSI): see Corrin (n 16) and there are therefore questions of autonomy and independence. Also to date little attention has been paid to their recommendations.

79 Most British funding today is through the European Union with some limited funding still coming from the Commonwealth and its various organisations.

80 See, eg, comments by I L W Richardson, 'Advising on Overseas Law Reform' (1978) 9 Victoria University of Wellington Law Review 385, in which he draws on his own experience as a legal reform adviser to Tonga.

81 This is not the only example of law reform in the area of family law, although these are relatively few. Others include the Adoption Act 2004 (Solomon Islands), the Adoption Act 2002 (Marshall Islands) and the Family Protection Act 2008 (Vanuatu).

82 D Beattie, Commission of Inquiry on the Courts (Fiji 1998).

83 English laws applying in Fiji included the Adoption of Infants Act 1945, Wills Act 1837 and Acts modelled on English law such as the Marriage Act (Cap 50) and the Matrimonial Causes Act (Cap 51). Only the last has been replaced by the Family Law Act 2003.

$84 \mathrm{Eg}$, there is provision to seek the assistance of counselling where children are involved (ss 50-51). Parents and the wider family are encouraged to arrive at a parenting plan (s 56).

85 Pt III, s 9. This takes account of the strong Christian element in Fijian society and the voice of various churches in the consultation process. 
this is the case, then the Act not only requires the spouses to have lived apart for a year and to demonstrate that the marriage has irretrievably broken down, but offers intervention in the form of counselling within the Family Court itself. Indeed, the Act offers marriage reconciliation counselling, family and child counselling and financial and property conciliation. The Act also provides for case assessment conferences, involving the registrar and/or the court counsellor, prior to any formal hearing, to inform the court of the future conduct of the case. The aim is to enable the parties - who may be unrepresented - to explore the issues in contention, consider the options and alternatives and, with assistance, to work towards solutions.

To monitor the administration of the new law and make recommendations for its improvement, the Act also established a Family Law Council to assist the Attorney General in matters such as legal aid relating to claims under the Act and the working of the Act. It also provides for accreditation of various organisations to assist with the practical purposes of the Act, for example, marriage education, counselling and the promotion of child welfare.

The Act has not, however, been without its critics both for the changes it has made and those it failed to make, and has encountered some challenges, ${ }^{86}$ especially in terms of putting the structures and personnel into place. Although it is early days yet to determine how successful it has been, there may be two fundamental flaws in the Fiji experience. First, much of the new law and its procedures are modelled on those that are found in Australia. These models may in themselves be flawed, ${ }^{87}$ or prove to be unsuitable for transplant to a country where the social, economic and political context is quite different. Second, the continued existence of these specialist courts is premised on specialist staff and adequate resources. In particular, there are considerable demands on human, physical and financial resources both in setting up the courts and their services and in maintaining them. ${ }^{88}$ Judges, magistrates and registry staff will require ongoing training and more court counsellors need to be trained, especially those outside the capital of Suva. Access to law for low-income clients will continue to be a problem, especially where there is insufficient legal aid and lawyers are not very interested in the low fees generated by most family work. There is a danger that, for the time being at least, the system will be heavily reliant on staff trained elsewhere, or volunteers from overseas. It is likely that civil society, churches and nongovernmental organisations will also need to be involved to make the Act work, for example, by providing a variety of support services such as supplementary counselling, safe housing, emergency financial assistance, legal advice and help in completing court forms. Economic and political instability in Fiji - which is currently under a military regime following a coup in 2006 - may jeopardise these. ${ }^{89}$ By Pacific standards these are expensive courts to run. Arguably, the new Act, although a brave move to shed the legacy of British law and genuinely patriate family law, will not be the panacea hoped for and may indeed

$86 \mathrm{Eg}$, proposals relating to de facto relationships and assisted reproduction had to be dropped because of opposition to, and misunderstanding about, these issues.

87 See R Graycar, 'Law Reform by Frozen Chook: Family Law Reform for the New Millennium' (2000) 29 Melbourne University Law Review 737; and R Field, 'Federal Family Law Reform in 2005: The Problems and Pitfalls for Women and Children of an Increased Emphasis on Post-Separation Informal Dispute Resolution' (2005) (5)1 Queensland University of Technology Law \& Justice Journal 28.

$88 \mathrm{Eg}$, case assessment conferences had to be abandoned early on due to a shortage of trained or accredited counsellors.

$89 \mathrm{Eg}$, a number of the judges and magistrates originally trained to officiate in these courts were dismissed or resigned from office in the aftermath of the 2006 coup. 
merely replace an old colonial legal framework with a new colonial one, neither of which are particularly suited to the socio-legal environment of Fiji. 90

Increasingly, the globalisation of law through treaties and conventions, and the advocacy of universal standards impacts on legal reform discourse, to the extent that even in small island states the locality of the law may have to give way to wider considerations - for example, human rights, trade imperatives, international policies on drug trafficking or money laundering. Although Narokobi might have hoped that law-making in newly independent Papua New Guinea would have meant 'building on our own rich soil first, and then merging it where necessary with the scattered soil of the Western laws', ${ }^{91}$ innovation in law-making is becoming increasingly restricted because very little interaction takes place at a purely local level. ${ }^{92}$ Law reform is therefore complex and challenging requiring inward and outward-looking strategies in order to take into account the particular context, culture and environment of the law on the domestic front and to give effect to international obligations or expectations.

There may be disappointment that the legal transformation that may have been hoped for at independence has not occurred in Pacific island states. ${ }^{93}$ However, the retention of introduced or received law in the light of the challenges mentioned above, as well as resource constraints, may be seen as having some advantages. First, it can be claimed that Pacific island countries already have a substantial body of law which, although perhaps a 'chaotic' legacy, ${ }^{94}$ has its roots in the developed world and provides a shared experience across nations that link island states with the wider international community. ${ }^{95}$ Weisbrot points out that this 'civilising mission' of law 'is more durable than colonialism itself because it informs many of the practices and policies beyond those of the decolonisation period'. ${ }^{96}$ Despite anti-colonial rhetoric, the emergence of a Pacific middle class with disposable wealth, the westernisation of life-styles and an agenda for economic development throughout the region have resulted in aspects of this 'mission' being internalised and an ambivalence about elevating the status of traditional laws and institutions. Second, the retention of this body of laws allows Pacific island states time to consider what their legal priorities are, while not leaving legal systems entirely without laws. Third, the existing legal framework provides a baseline for law amendment in a piecemeal way rather than root and branch reform. Fourth, it might also be pointed out that while much of the law introduced into the region appears dated in its country of origin, in the Pacific it may not seem out of place. For example, in family law, the retention of fault-based divorce, the criminalisation of abortion and homosexuality, and the total lack of legislative provision for cohabiting, unmarried heterosexual couples may not be out of step with the values of many Pacific islanders. These are, after all, societies which remain strongly

90 The Family Law Act is, eg, extremely cumbersome to read and difficult for local lawyers to understand.

91 Narokobi (n 32) 54.

92 And where matters are purely local they tend to fall under customary law and outside the remit of the state and the law reform agenda.

93 See Weisbrot (n 77); and see M A Ntumy, 'The Dream of a Melanesian Jurisprudence: The Purpose and Limits of Law Reform' in J Alecks and J Rannells, Custom at the Crossroads (eds) (University of Papua New Guinea 1995) 7.

94 A term used by J Corrin, 'Bedrock and Steel Blues: Finding the Law Applicable in Vanuatu' (1998) Commonwealth Law Bulletin 594, 608, although it might be added that the legacy of received law in Vanuatu was more chaotic than some other Pacific island countries.

95 L Benton, eg, points out that under colonial rule 'the law worked to tie disparate parts of empires and to lay the basis for exchanges of all sorts', Legal Regimes and Colonial Cultures: Legal Regimes in World History 1400-1900 (CUP 2002) 3.

96 Weisbrot (n 77) 43. 
patriarchal and in which the majority of the population are practising Christians. The emphasis given to tradition and custom and the centrality of the family and the church in daily life combine to create a conservatism in which advocacy for law reform is cautious.

Finally, as has been suggested, existing introduced legal principles can provide scope for innovation in the courts, as illustrated by judicial incorporation of the UNCRC into regional jurisprudence. This international convention is one of the few to which most Pacific island states are parties, and it provides courts with an additional legal resource for deciding matters pertaining to children. For example, in Vanuatu the court has been prepared to consider the UNCRC to support its decisions on the grant of custody of children, referring to the best interests of the child principle; ${ }^{97}$ in Fiji it has been called on in arriving at the calculation of child maintenance; ${ }^{98}$ in Samoa it has been applied in considering the punishment of banishment and its negative effects on children in the family; ${ }^{99}$ and in some cases courts have expressed a willingness to consider the convention even where there is evidence of a general reluctance to apply conventions which are not incorporated into domestic law. ${ }^{100}$ This judicial activism has been facilitated by residual English law. For example, in the Vanuatu case of Re Adoption Act 1958 (UK), Child M [2011] VUSC 16, the court opposed an inter-country adoption of a 13-year-old girl by prospective adoptive parents living in neighbouring New Caledonia, on the grounds that the 1993 Hague Convention (Convention for the Protection of Children and Cooperation in respect to Inter-country Adoptions) gives effect to Article 21 of the UNCRC. Despite recognising that Vanuatu is not a party to the Hague Convention, although it is a party to the UNCRC, the court exercising the discretion conferred on it under the UK law that applied - the Adoption Act 1958 - refused the application on the grounds that:

There is currently no guarantee that any responsible and suitable government body in New Caledonia would undertake any responsibility for assisting with the assessment of the prospective adoptive parents and, if the adoption did occur, the on-going supervision and monitoring of the adoption. It is also not clear what would occur with respect to the nationality of the child given that there is currently no input from the governments of either France or New Caledonia that might clarify that issue.

Clearly, the Adoption Act 1958 predates these international conventions. Nevertheless, it was used here to address an issue of growing concern in the region, that of inter-country adoption, and, arguably, this expansive interpretive approach sets a persuasive precedent for other Pacific jurisdictions also facing the challenges of inter-country adoption applications. ${ }^{101}$ It is also noticeable that in other areas of law where either there is no customary law in place, ${ }^{102}$ or that which exists is seen to be contrary to the fundamental rights provisions of constitutional bills of rights, ${ }^{103}$ or where alternative legal forms are being utilised to facilitate development, ${ }^{104}$ introduced legal principles and institutions may provide useful tools.

97 Molu v Molu (No 2) [1998] VUSC 15. See also Kong v Kong [2000] VUCA 8.

98 Murphy $v$ Ragg [2002] FJMC 2, in which it was held that the courts should give more emphasis to giving effect to the spirit and intendment of the UNCRC when dealing with any maintenance or divorce proceedings.

99 Leituala v Mauga [2004] WSSC 9.

$100 \mathrm{Eg}$, in Tonga in the case of Tone $v$ Police [2004] TOSC 36.

101 See S Farran, ‘South Pacific Children: The Law on Adoption and Issues of Concern' (2008) 6(2) New Zealand Family Law Journal 30.

$102 \mathrm{Eg}$, in contract or employment law.

$103 \mathrm{Eg}$, the use of banishment in Samoa, or the exchange of women as head-pay in Papua New Guinea.

$104 \mathrm{Eg}$, the use of trusts to manage land rents or timber royalties, or the use of leases to secure mortgage finance against land held under customary tenure. 


\section{Conclusion}

There may well have been hopes or expectations that on independence Pacific island countries would develop their own distinctive legal systems and eradicate the colonial laws that had been left in place or minimise their continuing relevance. It might also have been expected that customary laws and institutions would have come to the fore and dominated indigenous legal systems. For advocates of customary law, the common law is viewed as something of a pariah. Nevertheless, post-independence little has been done to foreground customary law, to reconcile customary law and received law, or to harmonise the different legal sources despite various suggested approaches. ${ }^{105}$ There are no doubt a number of reasons why this has not happened. Two in particular stand out. ${ }^{106}$ First, the complexity and diversity of custom and customary law makes it difficult to codify or apply at a national level, while at the same time the fact that many people's lives are governed outside the state system means that the two spheres of formal and informal law continue to exist in parallel, ${ }^{107}$ often with little intersection. ${ }^{108}$ Second, the confusion of introduced laws and uncertainty as to the extent of their application present considerable challenges for any patriation, harmonisation or unification project.

Consequently, and almost as a default situation, the legacy of English law continues to be relevant in the Pacific region. This is not so much due to the physical presence of judges and lawyers from England and Wales as to their interpretation of English laws, especially through caselaw. ${ }^{109}$ This, combined with the colonial history of introduced laws and legal institutions, ${ }^{110}$ the use of English as the language of instruction at the University of the South Pacific (where many young lawyers are now educated), and the secondment of legal advisers and personnel from other common law systems to Pacific island legal departments, ${ }^{111}$ has contributed to the contemporary state of the law in the region. Although there are many more indigenous judges and chief justices than there were 10 or 20 years ago, they are essentially trained in the common law tradition, so that they in turn, as members of the bench and Bar, ${ }^{112}$ ensure the survival of this legacy - at the expense

105 See, eg, A Angelo, 'Lo Bilong Yumi Yet' (1992) 22 Victoria University of Wellington Law Review, Monograph 4; J Corrin and J Zorn, 'Legislating Pluralism: Statutory "Developments" in Melanesian Customary Law' (2001) 46 Journal of Legal Pluralism 49; and the New Zealand Law Commission Report, Custom and Human Rights in the Pacific (2006).

106 There are many others, eg: the continued presence of ex-patriot judges and lawyers for many years after independence; lack of resources; unstable governments with fluctuating legislative agendas; lack of interest in law reform compared to economic development and lack of consensus on priorities; uncertainty as to the formal status of customary law; and lack of engagement with the state and by the state and its institutions in the lives of the majority of Pacific islanders.

107 'Formal' and 'informal' may be misleading terms because where customary law is recognised as a source of law by the state (eg, in the constitution) it has a formal status, although it is not 'state' law.

108 This is of course variable. In some countries appeals from traditional courts go to the state courts, or customary practices have to be adjudicated by the formal courts; or persons knowledgeable in custom are required to sit as assessors or advisers in the formal courts.

109 For some this is seen as a failure to develop a distinctive, Pacific, body of caselaw or jurisprudence. See Ntumy (n 93) and B Narokobi, 'In Search of Melanesian Jurisprudence' in P Sack and E Minchin (eds), Legal Pluralism: Proceedings of the Canberra Law Workshop VII (1986) 226.

110 The hierarchy of courts, eg, is essentially based on common law models as are rules of procedure and evidence, especially in non-custom courts: see J Corrin, Civil Procedure and the Courts in the South Pacific (Cavendish Publishing 2004). The system is consequently predominantly adversarial, although judges will on occasion adopt a more interventionist approach.

111 Notably, from Australia and New Zealand into state law offices, the offices of Attorney Generals, as legal draftspersons and as legal advisers and trainers.

112 Unlike England and Wales and, indeed, Scotland, the legal profession in Pacific island countries is not divided into solicitors and barristers/advocates. 
some might argue of developing indigenous legal systems. ${ }^{113}$ Moreover, the high court and appeal court benches of Pacific island countries continue to have a sizeable proportion of foreign common law judges drawn mainly from New Zealand and Australia ${ }^{114}$ and, where new laws are being drafted, regional experts - from Australia and New Zealand (or, in the case of countries such as Marshall Islands, Federated States of Micronesia or Palau, the United States of America) - are more likely to be engaged than those from further afield. ${ }^{115}$ While the influence of English law may be becoming less direct, being routed via other common law jurisdictions which in turn have their origins in English law, advances in information technology are making the law more accessible to local lawyers so that it is easier to refer to the caselaw and legislation of other Pacific island countries as well as the wider common law world. ${ }^{116}$

Therefore, although the influence of the English Bar and bench is not so immediate and direct as it was in the years of colonialism or even in the years immediately after independence, and in some cases legal transplants have been modified, hybridised or excised, nevertheless, when Pacific island judges trace the history of the law to justify the route they are taking today, invariably it is from the legacy of British (or more accurately English) laws. ${ }^{117}$ At the same time, it could be argued that the Pacific reception of the common law and the continuing application of this legacy in Pacific island courts has led to a form of patriation of jurisprudence through the development of a body of Pacific 'common law' in the region's courts by the Bar and bench. ${ }^{118}$ While it may be some time before barristers in England and Wales request to 'draw the court's attention' to a decision of a Pacific court (in the way that they might do with decisions from Canada, Australia or New Zealand, for example), a canoe can be paddled in more than one direction, especially if the oar is made of oak, and there may be some useful examples to be drawn from this emerging body of common law. ${ }^{119}$

113 See, eg, comments by Wiesbrot (n 77) and Ntumy (n 93).

114 In recent years some English judges have also sat on Pacific benches, including: Justice Coventry in Vanuatu and Fiji, Lord Slynn of Hadley and Justice Roger Chetwynd, together with the Irish judge Justice Edwin Goldsbrough (who also sat in Vanuatu) on the Court of Appeal in Solomon Islands. English judges have, of course, sat as members of the Privy Council when cases were referred to it: see from Fiji, eg, Marahaj $v$ Chand [1986] FJ-UKPC 5; from Samoa, Levave v Immigration Department (1979) 2 NZLR 74; and Lesa v Attorney General, see R G Glover (1982) New Zealand Law Journal 315 and E J Haughey in the same journal 317-19. In the period before and immediately after independence in 1980 Justice Frederick Cooke sat on the bench in Vanuatu.

115 While leaders such as Somare had declared that countries such as Papua New Guinea did not want 'imitation of the Australian, English or American legal systems' but 'a framework of laws and procedures that the people of Papua New Guinea can recognise as their own': M Somare, 'Law and the Needs of Papua New Guinea People' in J Zorn and P Bayne, Lo Bilong ol Manmeri: Crime, Compensation and Village Courts (University of Papua New Guinea 1975) 1; and the view of Narokobi that independence entailed 'the creation of our own laws, based on our own world view' (n 32) 54. Measures to meet these aspirations have been disappointing.

116 Examples are the Pacific Island Information Institute (PACLII) and linked sites such as AUSTLII, BALII and WorldLII.

117 See, eg, histories of: the paramountcy of the welfare principle in cases involving children explored in Hardeo $v$ Lata [2005] FJHC 410; the separate property of husband and wife Tavake v Tavake (n 53) and Goodhew $v$ Goodhew (n 75); the law on concealment of birth as a criminal offence Regina v Hong [2004] SBHC 33, and more recently pre-nuptial contracts Hadley $v$ Hadley (n 74).

118 Corrin (n 16) argues that the courts are not sufficiently critical of the applicability of the common law. That may be so, but there is also evidence that in a number of regional decisions there is careful reflection on the choice of caselaw being followed.

$119 \mathrm{Eg}$, these countries have written bills of rights which considerably pre-date the UK Human Rights Act 1998, have had to find coping strategies to deal with environment and sustainability issues and have centuries of experience of alternative dispute resolution. 
